\title{
Evaluasi Kebutuhan Ruang Parkir di Pasar Larangan Sidoarjo
}

\author{
Space Requirements Parking Evaluation at Larangan Sidoarjo \\ Market \\ Muammar Fahrul ${ }^{1}$, Adhi Muhtadi ${ }^{2}$, Hendro Sutowijoyo ${ }^{3}$ \\ 1,2,3 Prodi Teknik Sipil, Fakultas Teknik, Universitas Narotama, Jl. A.R. Hakim 51 Surabaya Telp: (031) \\ 5946404 \\ E-mail :muammarfahrul@gmail.com
}

\begin{abstract}
Abstrak
Pasar merupakan salah satu sentra kegiatan masyarakat di kawasan perkotaan. Seiring tumbuhnya jumlah kendaraan pribadi dan kegiatan perdagangan yang semakin tinggi maka masalah parkir di kawasan pasar akhirnya muncul. Permasalahan dalam penelitian ini adalah evaluasi kebutuhan ruang parkir di Pasar Larangan Sidoarjo. Evaluasi ini sangat penting dilakukan mengingat banyaknya kendaraan (sepeda motor dan mobil penumpang) yang menggunakan bahu Jl. Sunandar Priyo Sudarmo untuk kegiatan parkir selama berbelanja di Pasar Larangan Sidoarjo. Tujuan penelitian ini adalah menentukan kebutuhan tambahan ruang parkir di Pasar Larangan Sidoarjo. Metode yang digunakan dalam penelitian ini adalah melakukan perhitungan dan menganalisis karakteristik parkir yakni volume parkir, akumulasi parkir, durasi parkir, kapasitas parkir, serta tingkat pergantian (turn over). Hasil penelitian didapatkan bahwa kebutuhan ruang parkir yang harus disediakan untuk parkir kendaraan sepeda motor adalah 597 SRP (Satuan Ruang Parkir) dan untuk mobil 216 SRP. Maka diperlukan ruang parkir tambahan yakni 117 SRP untuk sepeda motor dan 136 SRP untuk mobil penumpang.
\end{abstract}

Kata Kunci: Evaluasi; mobil penumpang; pasar; ruang parkir; sepeda motor

\begin{abstract}
The market is one of the centers for community activities in urban areas. As the number of private vehicles grows and trading activities are getting higher, parking problems in the market area have finally emerged. The problem in this research is the evaluation of the parking space requirements in Larangan Market, Sidoarjo. This evaluation is very important to do considering the number of vehicles (motorbikes and passenger cars) that use the shoulder of Jl. Sunandar Priyo Sudarmo for parking activities while shopping at Pasar Larangan Sidoarjo. The purpose of this study was to determine the need for additional parking space at Larangan Market, Sidoarjo. The method used in this research is to calculate and analyze parking characteristics, i.e: parking volume, parking accumulation, parking duration, parking capacity, and turnover rate. The results showed that the parking space requirements that must be provided for parking motorbikes are 597 SRP (Parking Space Unit) and 216 SRP for cars. Then an additional parking space is required, namely 117 SRP for motorbikes and 136 SRP for passenger cars
\end{abstract}

Keywords: Evaluation; passenger cars; markets; parking spaces; motorbikes 


\section{PENDAHULUAN}

Perparkiran merupakan salah satu bagian yang penting dari kegiatan transportasi kota. Perparkiran juga menjadi salah satu masalah yang sering sekali dijumpai dalam hal transportasi, terutama dalam penyebab kemacetan yang sedang merajalela di berbagai kota besar yang sedang berkembang, begitupun di Indonesia. Masalah perparkiran juga akan muncul apabila kebutuhan parkir lebih besar dari fasilitas parkir yang tersedia.

Pertambahan jumlah penduduk dan perkembangan perekonomian pada saat ini memberikan dampak pada peningkatan pendapatan penduduk, sehingga menyebabkan peningkatan kepemilikan kendaraan pribadi, namun hal ini tidak diimbangi dengan pertambahan lahan parkir. Hal ini menyebabkan terjadinya kekurangan lahan parkir, yang menjadi masalah perparkiran di kota.

Dalam usaha menangani masalah sistem perparkiran, maka diperlukan perencanaan yang baik, yaitu lahan parkir yang mencukupi dan bentuk penentuan pola parkir yang tepat, dimana kebutuhan akan lahan parkir (demand) dan prasarana yang dibutuhkan (supply) harusalah seimbang dan disesuaikan dengan standard perparkiran (Dirjen Perhubungan Darat, 1998).

lokasi Pasar Larangan ini karena diwaktu hari libur atau hari-hari besar seperti hari raya idul fitri, natal dan tahun baru saat pagi dan sore hari, pukul 06.00 10.00 dan 16.00 - 18.00. Pasar ramai banyak nya pengunjung dan banyak juga yang mengunakan kendaraan pribadi sehingga menyebabkan volume ruang parkir untuk menampung semua kendaraan tersebut menjadi tidak bisa menampung semua kendaraan. dan sering terjadi pengunjung memarkir kendaraan pribadinya ditepi jalan raya saat daya tampung ruang parkir pasar penuh sehingga mengakibatkan kemacetan di ruas jalan tersebut.Sehingga agar mampu memberikan layanan yang baik dan meminimalkan berbagai masalahmasalah perparkiran dimasa yang akan datang. Sehingga, kami berencana melakukan studi yaitu "Evaluasi Kebutuhan Ruang Parkir di Pasar Larangan Sidoarjo"

\section{METODE}

Metode Penelitian adalah proses untuk mendapatkan data yang akan digunakan untuk keperluan penelitian. Untuk mendapatkan data yang mendukung penelitian ini adalah dengan melakukan survey parkir yaitu dengan melakukan pengamatan langsung di lapangan yang bertujuan untuk mendapatkan data fasilitas parkir yang telah ada dan menghitung kendaraan parkir untuk mendapatkan nilai akumulasi parkir, indeks parkir, durasi parkir, pergantian parkir dan kapasitas parkir.

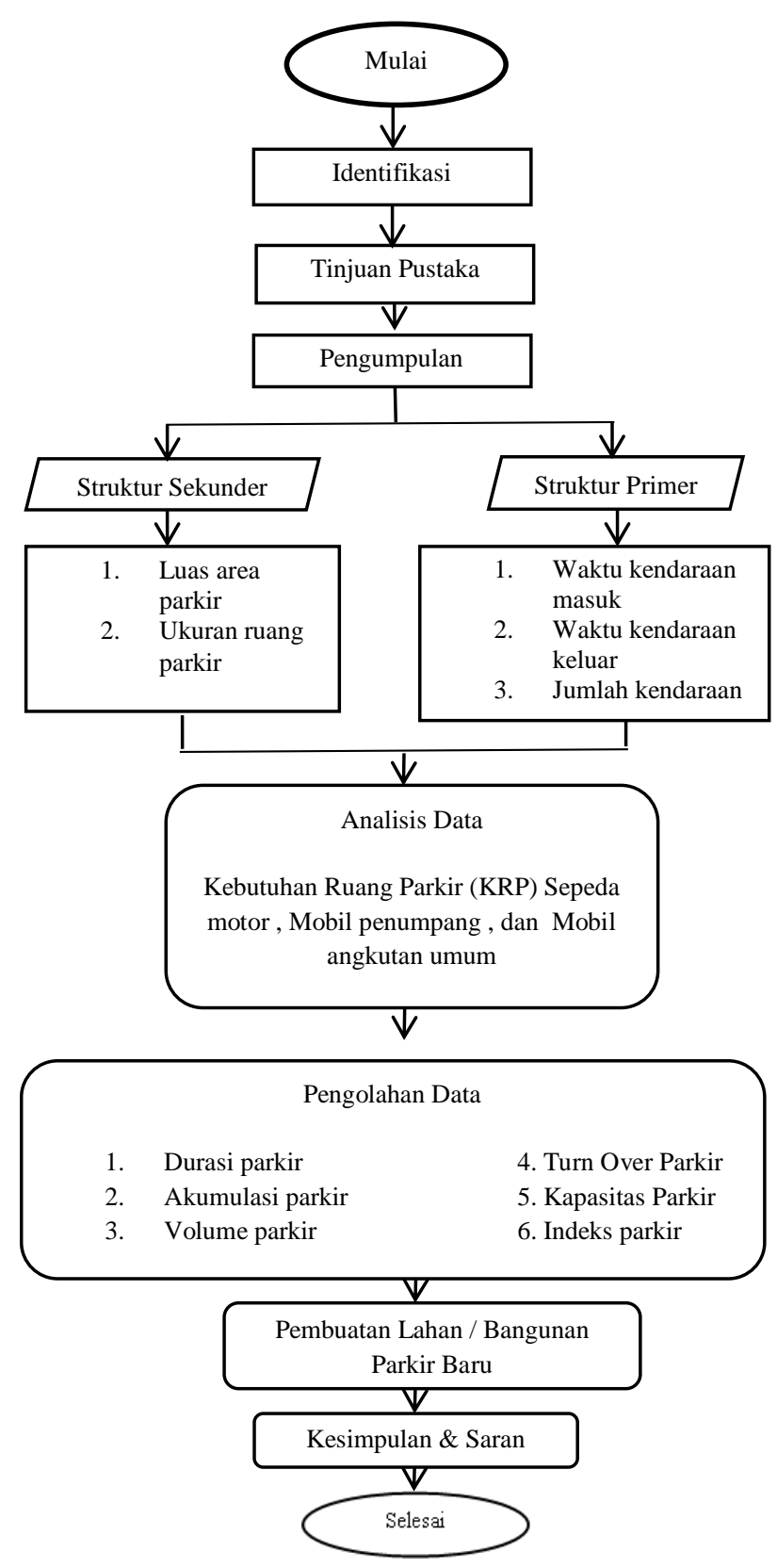

\section{LOKASI STUDI}

Lokasi studi berada di Pasar Larangan Sidoarjo yang terletak di Jl. Sunandar Priyo Sudarmo, Dusun Larangan, Kabupaten Sidoarjo. 


\section{PENGUMPULAN DATA}

Data diperoleh dari hasil survey yang dilakukan pada lokasi studi perparkiran. Data-data tersebut meliputi data arus keluar masuknya kendaraan di lahan parkir.

Tabel 1. Jumlah SRP existing di lokasi lahan parkir Pasar Larangan Sidoarjo

\begin{tabular}{ccc}
\hline NO & Jenis Kendaraan & SRP \\
\hline 1 & Sepeda Motor & 480 \\
\hline 2 & Mobil & 80 \\
\hline
\end{tabular}

\section{HASIL DAN PEMBAHASAN}

\section{Distribusi Kendaraan Keluar Masuk}

A. Jumlah maksimum kendaraan masuk dan keluar pada hari Minggu, 20 Desember 2020 dapat dilihat pada gambar grafik dibawah ini:

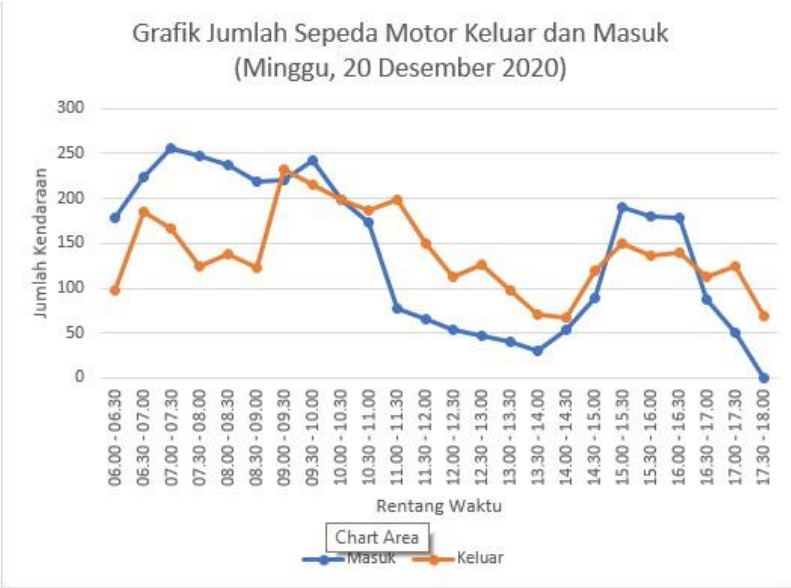

Gambar 1. Grafik jumlah sepeda motor masuk dan keluar hari minggu, 20 Des 2020

Pada grafik tersebut diketahui pada hari Minggu, 20 Desember 2020 jumlah maksimum sepeda motor yang masuk parkir terjadi pada pukul $07.00-07.30$ WIB sebanyak 256 kendaraan sedangkan untuk jumlah maksimum kendaraan yang keluar parkir terjadi pada pukul 09.00 - 09.30 WIB sebanyak 233 kendaraan.

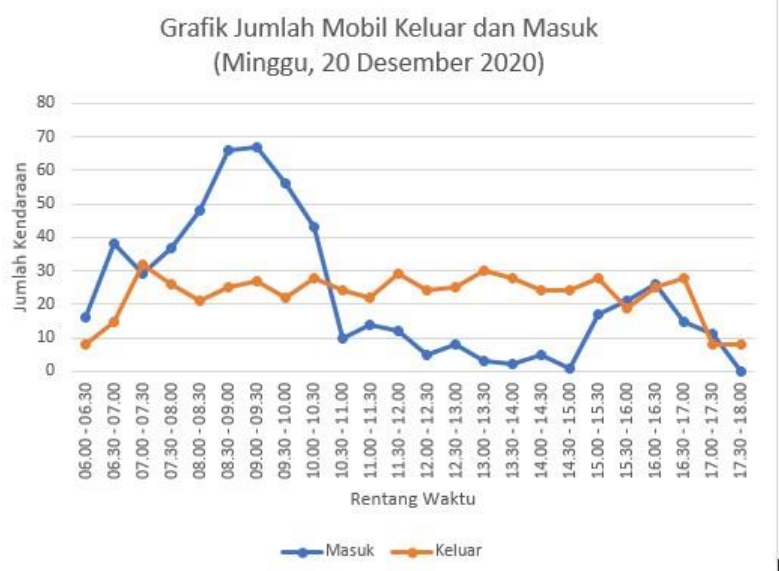

Gambar 2. Grafik jumlah mobil masuk dan keluar hari minggu, 20 Des 2020

Pada grafik tersebut diketahui pada hari Minggu, 20 Desember 2020 jumlah maksimum mobil yang masuk parkir terjadi pada pukul 09.00 - $09.30 \mathrm{WIB}$ sebanyak 67 kendaraan sedangkan untuk jumlah maksimum kendaraan yang keluar parkir terjadi pada pukul 07.00 - 07.30 WIB sebanyak 32 kendaraan.

B. Jumlah maksimum kendaraan masuk dan keluar pada hari Selasa, 22 Desember 2020 dapat dilihat pada gambar grafik dibawah ini:

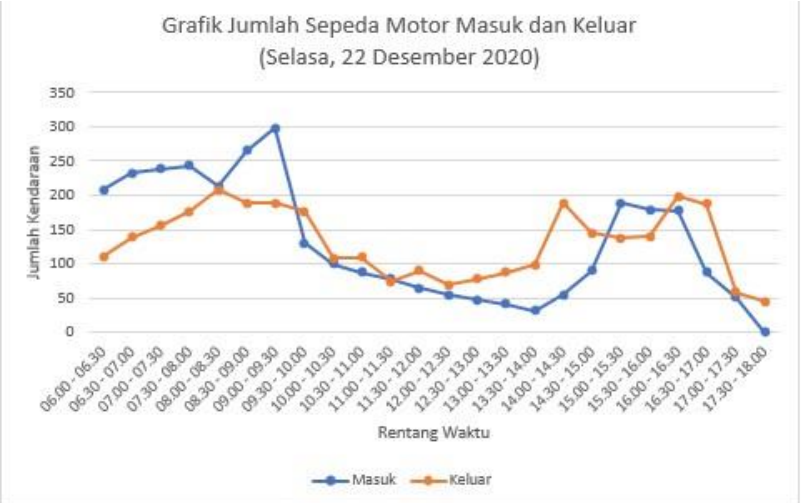

Gambar 3. Grafik jumlah sepeda motor masuk dan keluar hari selasa, 22 Des 2020

Pada grafik tersebut diketahui pada hari Selasa, 22 Desember 2020 jumlah maksimum kendaraan yang masuk parkir terjadi pada pukul $09.00-09.30 \mathrm{WIB}$ sebanyak 298 kendaraan sedangkan untuk jumlah maksimum kendaraan yang keluar parkir terjadi pada pukul 08.00 - 08.30 WIB sebanyak 208 kendaraan. 


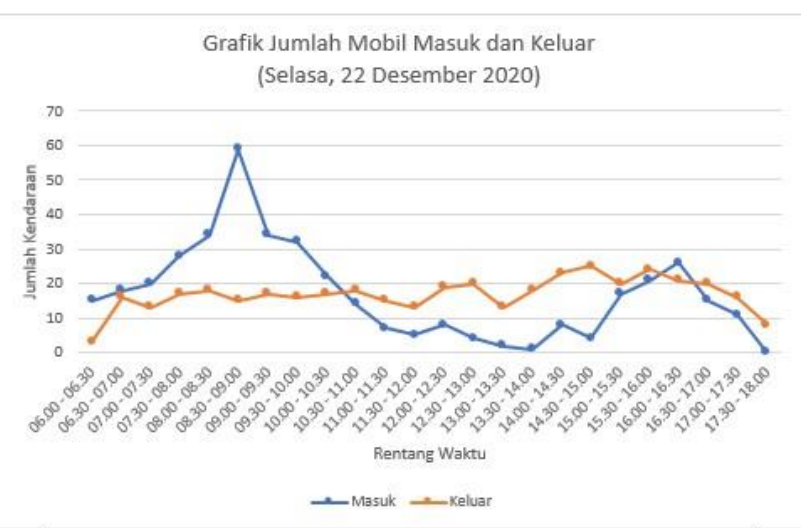

Gambar 4. Grafik jumlah mobil masuk dan keluar hari selasa, 22 Des 2020

Pada grafik tersebut diketahui pada hari Selasa, 22 Desember 2020 jumlah maksimum kendaraan yang masuk parkir terjadi pada pukul $08.30-09.00 \mathrm{WIB}$ sebanyak 59 kendaraan sedangkan untuk jumlah maksimum kendaraan yang keluar parkir terjadi pada pukul 14.30 - 15.00 WIB sebanyak 25 kendaraan.

\section{Akumulasi Parkir}

Akumulasi parkir adalah jumlah kendaraan yang parkir disuatu area dengan waktu tertentu. Akumulasi parkir sangat dipengaruhi oleh jumlah kendaraan yang keluar masuk area parkir pada periode waktu tertentu. Apabila kendaraan yang masuk area parkir semakin banyak dan sementara kendaraan yang keluar area parkir semakin sedikit, maka nilai akumulasi nya akan semakin besar. Dilihat dari lokasi yang ditinjau adalah pusat perdagangan yang memiliki jumlah pengunjung perhari cukup besar, maka peluang memiliki akumulasi besar sangat mungkin terjadi. Berikut ini besarnya akumulasi parkir pada survey berlangsung:

A. Akumulasi parkir kendaraan pada hari Minggu, 20 Desember 2020 dapat dilihat pada gambar grafik dibawah ini.

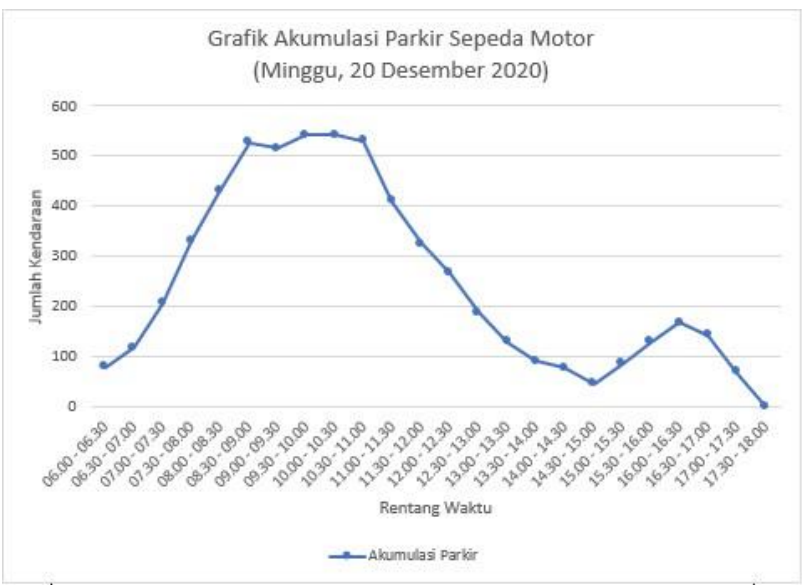

Gambar 5. Grafik Akumulasi Parkir sepeda motorhari minggu, 20 Des 2020

Dari gambar diatas dapat dilihat bahwa pada hari Minggu, 20 Desember 2020 akumulasi parkir sepeda motor maksimum terjadi pada pukul 09.30 - 10.00 WIB yakni sebesar 543 kendaraan.

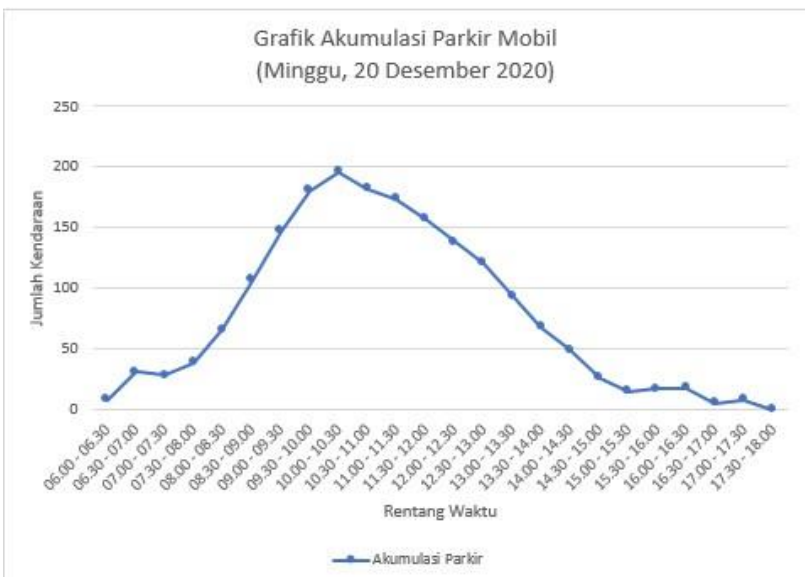

Gambar 6. Grafik Akumulasi Parkir mobilhari minggu, 20 Des 2020

Dari gambar diatas dapat dilihat bahwa pada hari Minggu, 20 Desember 2020 akumulasi parkir mobil maksimum terjadi pada pukul $10.00-10.30$ WIB yakni sebesar 196 kendaraan.

1. Akumulasi parkir kendaraan pada hari Selasa, 22 Desember 2020 dapat dilihat pada gambar grafik dibawah ini : 


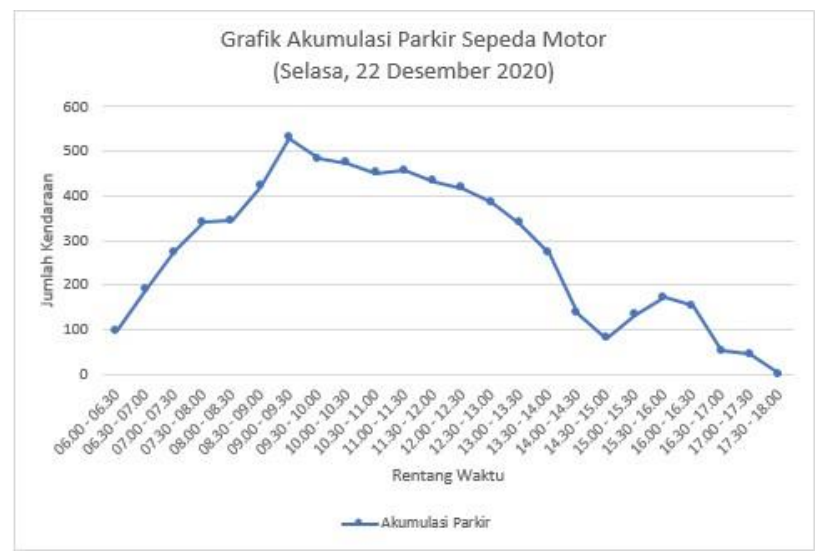

Gambar 7. Grafik Akumulasi Parkir sepeda motor hari selasa, 22 Des 2020

Dari gambar diatas dapat dilihat bahwa pada hari Selasa, 22 Desember 2020 akumulasi parkir sepeda motor maksimum terjadi pada pukul 09.00 - 09.30 WIB yakni sebesar 529 Kendaraan.

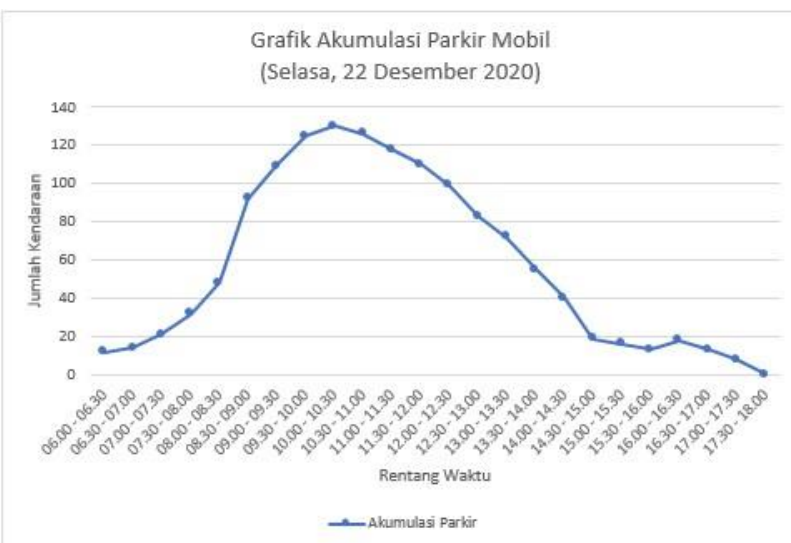

Gambar 8. Grafik Akumulasi Parkir mobil hari selasa, 22 Des 2020

Dari gambar diatas dapat dilihat bahwa pada hari Selasa, 22 Desember 2020 akumulasi parkir mobil maksimum terjadi pada pukul 10.00 - 10.30 WIB yakni sebesar 130 Kendaraan.

Bedasarkan akumulasi parkir maksimum pada Hari Minggu yang merupakan hari libur akhir pekan sehingga banyak pengunjung datang ke Pasar Larangan Sidoarjo. Tetapi kenyataan yang terjadi pada nilai akumulasi hari minggu dan hari selasa tersebut melampaui Kapasitas Statis yang tersedia yaitu sebesar 480 SRP untuk sepeda motor dan 80 SRP untuk mobil. Dengan hasil yang ada maka dapat dikatakan bahwa Kapasitas Statis yang tersedia di Pasar Larangan Sidoarjo sudah tidak dapat memenuhi kebutuhan ruang parkir yang dibutuhkan untuk hari minggu dan hari selasa.

\section{Volume Parkir}

Volume parkir adalah jumlah kendaraan yang terlibat dalam suatu beban parkir kendaraan per periode waktu tertentu, untuk lebih jelasnya bisa di lihat pada tabel dibawah ini :

Tabel 2. Kumulatif Kendaraan Masuk Volume Parkir

\begin{tabular}{ccccc}
\hline NO & Tanggal & $\begin{array}{c}\text { Waktu } \\
\text { Survey }\end{array}$ & $\begin{array}{c}\text { Kumulatif } \\
\text { Sepeda } \\
\text { Motor } \\
\text { Masuk }\end{array}$ & $\begin{array}{c}\text { Kumulatif } \\
\text { Mobil } \\
\text { Masuk }\end{array}$ \\
\hline 1 & $\begin{array}{c}20 \text { Des } \\
2020\end{array}$ & $\begin{array}{c}06.00- \\
18.00\end{array}$ & 3340 & 550 \\
\hline 2 & $\begin{array}{c}22 \text { Des } \\
2020\end{array}$ & $\begin{array}{c}06.00- \\
18.00\end{array}$ & 3158 & 405 \\
\hline
\end{tabular}

Dari tabel diatas dapat diketahui bahwa volume parkir maksium terjadi pada hari Minggu yang merupakan hari libur.

Berdasarkan data lama waktu parkir yang ada, dilakukan pengelompokan waktu tiap interval 30 menit berserta jumlah kendaraan dapat dilihat pada tabel nilai kebutuhan ruang parkir untuk lebih jelas lihat tabel dibawah ini :

Tabel 3. Lama Parkir dan Jumlah Sepeda Motor

\begin{tabular}{cccc}
\hline NO & Tanggal & $\begin{array}{c}\text { Interval } \\
\text { Parkir }\end{array}$ & $\begin{array}{c}\text { Jumlah } \\
\text { Kendaraan }\end{array}$ \\
\hline \multirow{2}{*}{1} & 20 Des & $00.30-$ & 687 \\
& 2020 & 00.59 & \\
\hline 2 & 22 Des & $00.30-$ & 597 \\
\hline
\end{tabular}

Dari tabel diatas dapat diketahui interval waktu parkir terbanyak rata-rata berada diatas setengah jam. Bedasarkan penjelasan diatas, maka dapat disimpulkan bahwa rata-rata pengunjung Pasar Larangan Sidoarjo lebih banyak berada dipasar selama sekitar 1 jam.

\section{Durasi Parkir}

Durasi parkir adalah lamanya waktu yang dibutuhkan kendaraan mulai masuk tempat parkir sampai meninggalkan tempat parkir. Durasi parkir dapat dihitung dengan mengunakan Rumus, berikut adalah contoh perhitungan durasi parkir :

Durasi Parkir $=\mathrm{T}_{\text {out }}-\mathrm{T}_{\text {in }}$.

$$
=06.00-06.30=30 \text { menit }
$$


Durasi parkir untuk parkir kendaraan Pasar Larangan Sidoarjo dapat dilihat pada tabel dibawah ini :

Tabel 4. Durasi Parkir Sepeda Motor Pasar Larangan Sidoarjo

\begin{tabular}{|c|c|c|c|}
\hline \multirow{2}{*}{ NO } & \multirow{2}{*}{$\begin{array}{c}\text { Lama } \\
\text { Parkir } \\
\text { (menit) }\end{array}$} & \multicolumn{2}{|c|}{$\begin{array}{c}\text { Jumlah Total Sepeda } \\
\text { Motor }\end{array}$} \\
\hline & & $\begin{array}{l}\text { Minggu, } 20 \\
\text { Des } 2020\end{array}$ & $\begin{array}{l}\text { Selasa, } 22 \\
\text { Des } 2020\end{array}$ \\
\hline 1 & 30 & 458 & 349 \\
\hline 2 & 60 & 637 & 537 \\
\hline 3 & 90 & 518 & 386 \\
\hline 4 & 120 & 365 & 295 \\
\hline 5 & 150 & 298 & 345 \\
\hline 6 & 180 & 234 & 244 \\
\hline 7 & 210 & 276 & 213 \\
\hline 8 & 240 & 148 & 287 \\
\hline 9 & 270 & 96 & 184 \\
\hline 10 & 300 & 77 & 115 \\
\hline 11 & 330 & 89 & 85 \\
\hline 12 & 360 & 76 & 57 \\
\hline 13 & 390 & 40 & 45 \\
\hline 14 & 420 & 5 & 5 \\
\hline 15 & 450 & 6 & 3 \\
\hline 16 & 480 & 5 & 3 \\
\hline 17 & 510 & 7 & 5 \\
\hline 18 & 540 & 5 & 0 \\
\hline 19 & 570 & 0 & 0 \\
\hline 20 & 600 & 0 & 0 \\
\hline & lah & 3340 & 3158 \\
\hline
\end{tabular}

Tabel 5. Durasi Parkir Mobil Pasar Larangan Sidoarjo

\begin{tabular}{ccrr}
\hline & \multirow{2}{*}{$\begin{array}{c}\text { Lama } \\
\text { NO }\end{array}$} & \multicolumn{2}{c}{ Jumlah Total Mobil } \\
\cline { 3 - 4 } & (menit) & $\begin{array}{c}\text { Minggu, 20 } \\
\text { Des 2020 }\end{array}$ & $\begin{array}{c}\text { Selasa, 22 } \\
\text { Des 2020 }\end{array}$ \\
\hline 1 & 30 & 78 & 54 \\
\hline 2 & 60 & 121 & 98 \\
\hline 3 & 90 & 53 & 67 \\
\hline 4 & 120 & 72 & 59 \\
\hline 5 & 150 & 61 & 22 \\
\hline 6 & 180 & 23 & 13 \\
\hline 7 & 210 & 15 & 22 \\
\hline 8 & 240 & 18 & 10 \\
\hline 9 & 270 & 12 & 16 \\
\hline 10 & 300 & 11 & 11 \\
\hline
\end{tabular}

\begin{tabular}{rrrr}
11 & 330 & 13 & 12 \\
\hline 12 & 360 & 19 & 11 \\
\hline 13 & 390 & 11 & 5 \\
\hline 14 & 420 & 17 & 2 \\
\hline 15 & 450 & 13 & 1 \\
\hline 16 & 480 & 10 & 1 \\
\hline 17 & 510 & 3 & 1 \\
\hline 18 & 540 & 0 & 0 \\
\hline 19 & 570 & 0 & 0 \\
\hline 20 & 600 & 0 & 0 \\
\hline \multicolumn{2}{c}{ Jumlah } & 550 & 405 \\
\hline
\end{tabular}

Setelah diperoleh durasi parkir untuk setiap kendaraan seperti pada contoh perhitungan diatas, maka dapat dikelompokkan durasi pada setiap kendaraan. Durasi parkir sepeda motor terbanyak yakni pada hari minggu sebanyak 687 kendaraan, lama parkir 60 menit. Sedangkan pada hari selasa durasi parkir terbanyak yakni 597 kendaraan, lama parkir 60 menit. Untuk durasi parkir mobil terbanyak yakni pada hari minggu sebanyak 121 kendaraan, lama parkir 60 menit. Sedangkan pada hari selasa durasi parkir terbanyak yakni 98 kendaraan, lama parkir 60 menit.

\section{A. Durasi Maksimum}

Dari hasil analisa durasi parkir, dapat diketahui durasi parkir maksimum. Durasi parkir maksimum sepeda motor parkir pada hari puncak kunjungan adalah 540 menit, pada hari minggu. Sebanyak 5 sepeda motor. Sedangkan durasi parkir maksimum mobil yakni 510 menit, pada hari minggu. Sebanyak 3 mobil

\section{B. Durasi Rata - Rata}

Dari Hasil analisa perhitungan pada durasi parkir, dapat diperoleh durasi rata-rata mengunakan rumus : Durasi rata-rata Motor $=\frac{\text { Lama Parkir } x \text { Total Parkir }}{\text { Jumlah Total Parkir }}$

Hari minggu, 20 desember $2020=\frac{457500}{3340}=136.98$ menit

Hari selasa, 22 desember $2020=\frac{479850}{3158}=151.95$ menit

Durasi rata-rata mobil $=\frac{\text { Lama Parkir } \times \text { Total Parkir }}{\text { Jumlah Total Parkir }}$

Hari minggu, 20 desember $2020=\frac{85050}{550}=25.46$ menit 
Hari selasa, 22 desember $2020=\frac{53040}{405}=16.80$ menit

\section{Kapasitas}

\section{A. Kapasitas Statis}

Kapasitas parkir statis pada halaman parkir di Pasar Larangan Sidoarjo tidak perlu dilakukan pengukuran ulang karena dapat dihitung langsung melalui ukuran slot parkir kendaraan yang ada. Kapasitas statis maksimal ruang parkir di Pasar Larangan Sidoarjo sebesar 480 SRP untuk sepeda motor, sedangkan untuk mobil sebesar 80 SRP.

\section{B. Kapasitas Dinamis}

Kapasitas dinamis merupakan kemapuan suatu lahan parker untuk menampung kendaraan yang mempunyai karakteristik parkir yang berbeda. Perhitungan kapasitas dinamis dapat dihitung dengan mengunakan Rumus yang ada pada berikut, ini adalah contoh perhitungannya :

Keterangan :

$\mathrm{Ks}=$ Kapasitasstatis, (SRP)

$\mathrm{T}=$ Lamanya pengamatan dilahan parkir dalam jam

D = Rata-rata durasi parkir selama periode waktu pengamatan (jam)

$\mathrm{F}=$ Faktor pengurangan, besarnya antara $0,85 \mathrm{~s} / \mathrm{d}$ 0,95

Kapasitas Dinamis $=\frac{\mathrm{KsxT}}{\mathrm{D}} x F$

Sepeda Motor $=\frac{480 \times 12}{\frac{136.97}{30}} \times 0.85=1072$ Kendaraan

Mobil $=\frac{80 \times 12}{\frac{25.46}{30}} \times 0.85=961$ Kendaraan

Dari perhitungan kapasitas dinamis parkir kendaraan di Pasar Larangan Sidoarjo untuk sepeda motor dengan durasi rata-rata 136.97 menit, dengan kapasitas statis 480 SRP, serta waktu pengamatan selama 12 jam, diperoleh kapasitas dinamis sebesar 1072 kendaraan. Sedangakan untuk mobil durasi rata-rata 25.46 menit, dengan kapasitas statis 80 SRP, serta waktu pengamatan selama 12 jam, diperoleh kapasitas dinamis sebesar 961 kendaraan.

\section{Indeks Parkir}

Indeks parkir merupakan presentase dari akumulasi jumlah kendaraan pada selang waktu tertentu dibagi dengan ruang parkir yang tersedia dikalikan $100 \%$. Perhitungan indeks parkir dapat dihitung mengunakan rumus yang ada pada persamaan (2.4) berikut contoh perhitungannya.

Indeks Parkir $=\frac{\text { Akumulasi Parkir }}{\text { KapasitasParkir }} \times 100 \%$

- Sepeda Motor :

Indeks Parkir Hari Minggu $=\frac{543}{480} \times 100 \%=113.13 \%$ Indeks Parkir Hari Selasa $=\frac{529}{480} \times 100 \%=110.21 \%$

- Mobil :

Indeks Parkir Hari Minggu $=\frac{196}{80} \times 100 \%=245 \%$

Indeks Parkir Hari Selasa $=\frac{130}{80} \times 100 \%=162.5 \%$

Dari perhitungan diatas dapat dilihat bahwa kapasitas statis sepeda motor sebanyak 480 SRP pada Hari Minggu lebih kecil dari pada akumulasi maksimum kendaraaan yang sebanyak 543 SRP. Sedangakan pada Hari Selasa lebih besar pada akumulasi maksimum sepeda motor yang sebanyak 529 SRP. untuk kapasitas statis mobil sebanyak 80 SRP pada Hari Minggu lebih kecil dari pada akumulasi maksimum kendaraaan yang sebanyak 196 SRP. Sedangakan pada Hari Selasa lebih besar pada akumulasi maksimum sepeda motor yang sebanyak 130 SRP.

Dari perhitungan diperoleh indeks parkir sepeda motor pada Hari Minggu sebesar $113.13 \%$ dan $110.21 \%$ untuk Hari Selasa ini berarti bahwa kendaraan yang ada di lahan Parkir Pasar Larangan Sidoarjo tersebut melebihi dari kapasitas parkir yang telah disediakan, sedangkan dari perhitungan indeks parkir mobil pada Hari Minggu sebesar 245\% dan $162.5 \%$ untuk Hari Selasa ini berarti kendaraan yang ada di lahan parkir tersebut melebihi dari kapasitas yang telah disediakan. Sehingga dapat disimpulkan bahwa kapasitas lahan parkir kendaraan untuk sepeda motor dan mobil di Pasar Larangan Sidoarjo pada Hari Minggu dan Selasa kapasitas lahan parkir tidak memenuhi, dikarenakan melebihi $100 \%$ dari kapasitas parkir yang disediakan. 


\section{Turnover Parkir}

Tingkat pergantian diperoleh dari jumlah kendaraan yang telah menggunakan lahan parkir pada selang waktu tertentu dibagi dengan ruang parkir yang tersedia.

- Sepeda Motor

Turnover Hari Minggu $=\frac{\text { Volume Parkir hari minggu }}{\text { Kapasitas Parkir }}$

$$
=\frac{3340}{480}=6.95
$$

Turnover Hari Selasa $=\frac{\text { Volume Parkir hari selasa }}{\text { Kapasitas Parkir }}$

$$
=\frac{3158}{480}=6.57
$$

- Mobil

$$
\begin{aligned}
\text { Turnover Hari Minggu } & =\frac{\text { Volume Parkir hari minggu }}{\text { Kapasitas Parkir }} \\
& =\frac{550}{80}=6.87 \\
\text { Turnover Hari Selasa } & =\frac{\text { Volume Parkir hari selasa }}{\text { Kapasitas Parkir }} \\
& =\frac{405}{80}=5.06
\end{aligned}
$$

Dari hasil perhitungan turnover diatas, dapat disimpulkan bahwa selama waktu pengamatan pada hari minggu setiap SRP Sepeda Motor mengalami pergantian rata-rata sebanyak 6.95 kali, sedangakan selama waktu pengamatan pada hari selasa setiap SRP mengalami pergantian rata-rata sebanyak 6.57 kali. Untuk waktu pengamatan pada hari minggu setiap SRP Mobil mengalami pergantian rata-rata sebanyak 6.87 kali, sedangakan selama waktu pengamatan pada hari selasa setiap SRP mengalami pergantian rata-rata sebanyak 5.06 kali. Turnover parkir dapat dilihat pada tabel dibawah ini :

Tabel 6. Turnover Parkir Kendaraan Pasar Larangan Sidoarjo

\begin{tabular}{ccccc}
\hline NO & Tanggal & $\begin{array}{c}\text { Kapasitas } \\
\text { Statis } \\
\text { (KRP) }\end{array}$ & $\begin{array}{c}\text { Volume } \\
\text { Kendaraan }\end{array}$ & $\begin{array}{c}\text { Turn } \\
\text { Over } \\
\text { Parkir }\end{array}$ \\
\hline 1 & $\begin{array}{c}20 \text { Des } \\
2020\end{array}$ & 480 & 3340 & 6.95 \\
\hline 2 & $\begin{array}{c}22 \text { Des } \\
2020\end{array}$ & 480 & 3158 & 6.57 \\
\hline 3 & $\begin{array}{c}20 \text { Des } \\
2020\end{array}$ & 80 & 550 & 6.87 \\
\hline
\end{tabular}

\begin{tabular}{ccccc}
4 & 22 Des & 80 & 405 & 5.06 \\
\hline
\end{tabular}

\section{Okupansi}

Okupansi adalah akumulasi kendaraan pada selang waktu tertentu dibagi dengan ruang parkir yang tersedia dikalikan $100 \%$. berikut ini contoh perhitungannya :

$$
\begin{aligned}
& \text { Okupansi Hari Minggu }= \\
& \frac{\text { Banyak Ruang Yang Ditempati }}{\text { Total Ruang Tersedia }} \times 100 \%=\frac{80}{480} \times 100 \% \\
& =16.67 \%(\text { jam } 06.00-06.30) \\
& \text { Okupansi Hari Selasa }= \\
& \frac{\text { Banyak Ruang Yang Ditempati }}{\text { Total Ruang Tersedia }} \times 100 \%=\frac{97}{480} \times 100 \% \\
& =20.21 \%(\text { jam } 06.00-06.30)
\end{aligned}
$$

Dari perhitungan diatas diperoleh okupansi sepeda motor maksimum sebesar $113.13 \%$ jam 09.30 10.00 dan okupansi mobil maksimum sebesar 245\% jam 10.00 - 10.30 di Hari Minggu. Sedangkan pada Hari Selasa okupansi sepeda motor maksimum sebesar $110.21 \%$ jam 06.30 - 07.00 dan okupansi mobil maksium sebesar $162.50 \%$ pada jam 10.00 10.30

\section{Kebutuhan Ruang Parkir (KRP)}

Kebutuhan ruang parkir (KRP) adalah jumlah ruang parkir yang dibutuhkan oleh kendaraan untuk parkir pada suatu lahan, yang besarnya dipengaruhi oleh berbagai faktor. Untuk memperkirakan kebutuhan ruang parkir dapat diperkirakan perhitungan dibawah ini :

$\mathrm{KRP}=\mathrm{F} 1 \times \mathrm{F} 2 \times$ Volume Parkir Harian

F1 = Faktor akumulasi

F2 = Faktor fluktuasi (menurut Dirjen Perhubungan Darat $1,1-1,25)$ untuk perencanaan disarankan 1,1

Kebutuhan ruang parkir sepeda motor hari Minggu, 20 Desember 2020 Dimana :

$\mathrm{F} 1=\frac{\text { Akumulasi Maksimum }}{\text { Volume Parkir }} \times 100 \%$ 
$\mathrm{KRP}=\mathrm{F} 1 \quad \mathrm{x}$ F2 $\mathrm{x}$ Vol. Parkir Harian $=\left(\frac{543}{3340} \times 100 \%\right) \times 1,1 \times 3340=543 \times 1,1=597 \mathrm{SRP}$

Kebutuhan ruang parkir mobil hari Minggu, 20 Desember 2020 Dimana :

$\mathrm{F} 1=\frac{\text { Akumulasi Maksimum }}{\text { Volume Parkir }} \times 100 \%$

KRP $=$ F1 $\times$ F2 $x$ Vol Parkir Harian

$=\left(\frac{196}{550} \times 100 \%\right) \times 1,1 \times 550=196 \times 1,1=216 \mathrm{SRP}$

Kebutuhan ruang parkir sepeda motor hari Selasa, 22 Desember 2020 Dimana :

$\mathrm{F} 1=\frac{\text { Akumulasi Maksimum }}{\text { Volume Parkir }} \times 100 \%$

$\mathrm{KRP}=\mathrm{F} 1 \times \mathrm{F} 2 \times$ Vol Parkir Harian

$=\left(\frac{529}{3158} \times 100 \%\right) \times 1,1 \times 3158=529 \times 1,1=582 \mathrm{SRP}$

Kebutuhan ruang parkir mobil hari Selasa, 22 Desember 2020 Dimana :

$\mathrm{F} 1=\frac{\text { Akumulasi Maksimum }}{\text { Volume Parkir }} \times 100 \%$

$\mathrm{KRP}=\mathrm{F} 1 \times$ F2 $\times$ Vol Parkir Harian

$=\left(\frac{130}{405} \times 100 \%\right) \times 1,1 \times 405=130 \times 1,1=143 \mathrm{SRP}$

Dari perhitungan diatas didapatkan hasil dari kebutuhan ruang parkir (KRP) sepeda motor pada Hari Minggu yaitu sebesar 597 SRP dan 582 SRP pada Hari Selasa. Jika dibandingakan dengan kapasitas statis yang tersedia (lihat tabel 15) yaitu sebesar 480 SRP untuk parkir kendaraan maka tidak mencukupi kebutuhan parkir yang dibutuhkan. Dan kebutuhan ruang parkir (KRP) mobil pada Hari Minggu yaitu sebesar 216 SRP dan 143 SRP pada Hari Selasa. Jika dibandingkan dengan kapasitas statis yang tersedia yakni 80 SRP maka kebutuhan parkir pada hari itu juga tidak mencukupi kebutuhan parkir. Rekapitulasi kebutuhan ruang parkir dapat dilihat pada tabel dibawah ini :

Tabel 7. Kebutuhan Ruang Parkir Pasar Larangan Sidoarjo

\begin{tabular}{|c|c|c|c|c|c|c|c|c|}
\hline No & Tanesel & $\begin{array}{c}\text { kenis } \\
\text { Rendaraass }\end{array}$ & $\begin{array}{l}\text { Volame } \\
\text { Kendaraas }\end{array}$ & $\begin{array}{l}\text { Akumulasi } \\
\text { Max } \\
\text { kendaraan }\end{array}$ & $\mathrm{F} 1$ & $\begin{array}{l}\text { KAP } \\
\text { (SAP) }\end{array}$ & 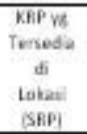 & $\begin{array}{l}\text { Mencukupi } \\
\text { / tuk } \\
\text { mentukupi }\end{array}$ \\
\hline 1 & $\begin{array}{c}20 \text { Des } \\
2020\end{array}$ & $\begin{array}{l}\text { Sepeda } \\
\text { Motor }\end{array}$ & 3340 & 543 & $16,26 \%$ & 597 & 480 & $\begin{array}{c}\text { Sdis } \\
\text {-encukup }\end{array}$ \\
\hline 2 & $\begin{array}{c}20 \mathrm{Des} \\
2020\end{array}$ & Mebil & 550 & 196 & $35,64 \mathrm{x}$ & 216 & 80 & $\begin{array}{c}\text { lds } \\
\text { centukup }\end{array}$ \\
\hline 3 & $\begin{array}{l}22 \text { Des } \\
2020\end{array}$ & $\begin{array}{l}\text { Sepede } \\
\text { Mator }\end{array}$ & 3158 & 529 & $16,75 \mathrm{~K}$ & 582 & 480 & $\begin{array}{c}\text { Ids } \\
\text { mentukup }\end{array}$ \\
\hline 4 & $\begin{array}{c}22 \text { Des } \\
2020\end{array}$ & Mabil & 405 & 130 & $32,10 \mathrm{~s}$ & 143 & 80 & $\begin{array}{c}d S k \\
\text { mencukup }\end{array}$ \\
\hline
\end{tabular}

dari hasil analisa perhitungan diatas, didapatkan hasil dari kebutuhan ruang parkir (KRP) sepeda motor pada Hari Minggu yaitu 597 SRP dan pada Hari Selesa 582 SRP. Jika dibandingkan dengan kapasitas statis yang ada yaitu sebesar 480 SRP, sedangkan untuk hasil dari kebutuhan ruang parkir (KRP) mobil pada Hari Minggu yaitu 216 SRP dan pada Hari Selesa 143 SRP Jika dibandingkan dengan kapasitas statis yang ada yaitu sebesar 80 SRP, serta berdasarkan hasil studi Direktorat Jendral Perhubungan Darat (1998, hal 72) yaitu sebesar 520 SRP, maka ini berarti bahwa kendaraan yang berada pada lahan tersebut lebih besar dari kapasitas yang telah di sediakan (kapasitas statis dan Direktorat Jendral Perhubungan Darat, 1998) sehingga dapat disimpulkan bahwa kapasitas lahan parkir tidak memenuhi.

Hasil analisa dan perhitungan didapatkan kebutuhan ruang parkir (KRP) sepeda motor sebesar 597 SRP pada Hari Minggu dan 582 SRP pada Hari Selasa. Jika dibandingkan dengan kapasitas statis (eksisting) sebesar 480 SRP, Sedangkan kebutuhan ruang parkir (KRP) mobil sebesar 216 SRP pada Hari Minggu dan 143 SRP pada Hari Selasa. Jika dibandingkan dengan kapasitas statis (eksisting) sebesar 80 SRP maka lahan parkir yang ada saat ini sudah tidak dapat menampung lagi karena terdapat kekurangan sebesar 117 SRP untuk sepeda motor dan 136 SRP untuk mobil. Perhitungan kebutuhan ruang parkir untuk memprediksi 5 tahun yang akan datang sebagai berikut :

- Sepeda motor :

$\operatorname{SRP} \times(1+\mathrm{i})^{5}=117 \times(1+0.16)^{5}=245 \mathrm{SRP}$

- Mobil :

$\operatorname{SRP} \times(1+i)^{5}=136 \times(1+0.16)^{5}=286 \mathrm{SRP}$

Keterangan :

$\mathrm{i}=$ pertumbuhan sepeda motor pertahun

Demikian, didapat rekomendasi yaitu dengan cara pembukaan lahan parkir baru di sekitar lahan kosong yang berada di sekitar pasar. Melihat hasil kebutuhan ruang parkir pada kendaraan, dapat direncanakan 
dengan penambahan gedung parkir bertingkat dan menambah jumlah ruang parkir untuk kendaraan.

\section{PENUTUP}

\section{Simpulan}

Bedasarkan hasil analisa dan pembahasan pada penelitian ini didapat beberapa kesimpulan yaitu :

1. Karakteristik parkir pada lahan parkir Pasar Larangan Sidoarjo terdiri dari :

a. Durasi parkir maksimum sepeda motor yakni 540 menit pada hari minggu dengan total 5 kendaraan dan durasi parkir maksimum mobil yakni 510 menit pada hari minggu dengan total 3 kendaraan.

b. Durasi parkir rata-rata sepeda motor pada Hari Minggu yakni 136.98 menit dan Hari Selasa 151.95 menit. Sedangkan untuk durasi parkir rata-rata mobil pada Hari Minggu yakni 25.46 menit dan Hari Selasa 16.80 menit.

c. Akumulasi maksimum parkir kendaraan sepeda motor adalah sebesar 543 pada Hari Minggu. Sedangkan akumulasi maksimum parkir kendaraan mobil adalah 196 pada Hari Minggu.

d. Volume parkir masuk maksimum sepeda motor yaitu pada hari Minggu sebesar 256 kendaraan, sedangkan jumlah maksimum sepeda motor yang keluar parkir sebanyak 233 kendaraan. Untuk volume parkir masuk maksimum mobil yaitu pada hari Minggu sebesar 67 kendaraan, sedangkan jumlah maksimum mobil yang keluar parkir sebanyak 32 kendaraan.

e. Indeks parkir sepeda motor pada Hari Minggu adalah sebesar 113.13\% sedangkan indeks parkir kendaraan pada Hari Selasa yakni sebesar $110.21 \%$ dan untuk indeks parkir mobil pada Hari Minggu adalah sebesar 245\% sedangkan indeks parkir kendaraan pada Hari Selasa yakni sebesar $162.5 \%$.

f. Kapasitas statis yang tersedia dia lahan parkir Pasar Larangan Sidoarjo adalah 480 SRP untuk sepeda motor dan 80 SRP untuk mobil. Kapasitas dinamis sepeda motor adalah 1072 kendaraan dan untuk kapasitas dinamis mobil yakni 961 kendaraan.

g. Turnover parkir sepeda motor pada Hari Minggu adalah 6.95 kali dan pada Hari Selasa adalah 6.57 kali. Untuk Turnover parkir mobil pada Hari Minggu adalah
6.87 kali dan pada Hari Selasa adalah 5.06 kali.

h. Okupansi maksimum untuk kendaraan sepeda motor parkir pada Hari Minggu $113.13 \%$ (jam 09.30 - 10.00) dan pada Hari Selasa $110.21 \%$ (jam 06.30 07.00). dan Okupansi maksimum untuk kendaraan mobil parkir pada Hari Minggu 245\% (jam 10.00 - 10.30) dan pada Hari Selasa $162.50 \%$ (jam $10.00-$ 10.30).

2. Kebutuhan ruang parkir (KRP) yang harus disediakan untuk parkir kendaraan sepeda motor adalah 597 SRP dan untuk mobil 216 SRP maka diperlukan ruang / lahan parkir tambahan untuk memenuhi kebutuhan ruang parkir yang tersedia.

3. Dari hasil analisa perhitungan keseluruhan, dapat disimpulkan bahwa kapasitas lahan parkir untuk sepeda motor yang ada sekarang tidak mencukupi kebutuhan parkir, masih kurang 117 SRP. Sedangkan untuk kapasitas lahan parkir untuk mobil juga tidak mencukupi kebutuhan parkir, masih kurang 136 SRP.

4. Untuk analisa kebutuhan parkir untuk 5 tahun yang akan datang. Memerlukan penambahan SRP yakni untuk sepeda motor sebesar 245 SRP dan mobil 286 SRP.

\section{Saran}

Bedasarkan hasil penelitian ini, terdapat hal penting sebagai saran yang nantinya untuk pengembangan penelitian lebih lanjut tentang perparkiran, yaitu :

1. Penelitian ini dapat dikembangkan untuk mengevaluasi standar kebutuhan ruang parkir dengan mengambil objek studi selain Pasar Larangan Sidoarjo, seperti : pusat perkantoran, apartemen, pasar swalayan, sekolah / perguruan tinggi, tempat wisata, hotel atau penginapan, dan lain-lain.

2. Kebutuhan ruang parkir pada Pasar Larangan Sidoarjo perlu dilakukan penambahan jumlah tempat parkir untuk kendaraan sepeda motor dan mobil. Jika kebutuhan lahan parkir dipasar larangan tidak mencukupi bisa membeli/megunakan lahan kosong yang tersedia di sekitar pasar (lihat gambar lampiran 5). Penambahan ruang parkir bisa dengan cara membuat gedung parkir bertingkat dan dibuat senyaman mungkin untuk pengendara melakukan maneuver.

3. Untuk kelancaran arus lalu lintas pada jalan masuk dan keluar, serta sirkulasi di dalam ruang parkir, maka pengantian rambu Proteksi/Juni 2021 Volume 3 No. 1 
penunjuk arah dengan yang lebih besar dan jelas, sangat diperlukan.

\section{DAFTAR PUSTAKA}

Direktorat Jendral Perhubungan Darat. 1998. Pedoman Teknis Penyelenggaraan Fasilitas Parkir. Keputusan Direktur Jendral Perhubungan Darat. Jakarta.

Direktorat Jendral Perhubungan Darat. 1998. Pedoman Perencanaan dan Pengoperasian Fasilitas Parkir. Direktorat Bina Sistem Lalu Lintas Angkutan Kota. Jakarta

Eko Aprianto, Baharuddin Hamzah, Ria wikantari R. 2014. Infrastruktur Parkir Pada Bangunan Komersial di Makassar. Universitas Hasanuddin Makasar.

Samsul Arif Hidayat, Erick Luckita Saputra. 2015, Studi Perencanaan Gedung Parkir Terpusat Universitas Brawijaya. Universitas Brawijaya.

Muhammad Zulfikri, Heru Sufianto, Tito Haripradianto. 2015. Perencangan Gedung Parir Terintergrasi di Universitas Brawijaya dengan Pendekatan Green Façade. Universitas Brawijaya.
Ismi Nur Azizah. 2015. Analisis Kebutuhan dan Alternatif Penyelesaian Masalah Ruang Parkir di Jurusan Teknik Sipil Institut Teknologi Sepuluh Nopember Surabaya. Institut Teknologi Sepuluh Nopember Surabaya.

Risnauli Sumiati Sinaga. 2015. Evaluasi Kinerja Fasilitas Ruang Pejalan Kaki dan Ruang Parkir di Pusat Perbelanjaan Gatot Subroto, Medan. Institut Teknologi Sepuluh Nopember Surabaya.

Wibisono, R Endro., \& Mahardi, Purwo. 2020. "Analysis on Calculation of Vehicle Operating Cost (VOC) Before and After Flyover \& Road Widening Operation at Gedangan Intersection in Sidoarjo Regency". Journal of Physics: Conference Series, Vol. 1569 No.4, 2020, 042017. 